\title{
Inter-Relationship of Soil-Forage-Plasma, and Milk Chromium: A Case Study in an Arid Region of Pakistan
}

Muhammad Danish ${ }^{1 *}$, Nazir Ahmad ${ }^{2}$, Ihsan Sharif ${ }^{3}$, Mirza Naveed Shahzad ${ }^{4}$, Syed Sibtain Raza Rizvi ${ }^{5}$ and Muhammad Faizan Nazar ${ }^{1}$

${ }^{1}$ Department of Chemistry, University of Gujrat, Gujrat, Pakistan

${ }^{2}$ Lab of Organometallics, Catalysis \& Ordered Materials, Wuhan University of Technology, China

${ }^{3}$ Department of Chemistry, University of Sargodha, Sargodha, Pakistan

${ }^{4}$ Department of Statistics, University of Gujrat, Gujrat, Pakistan

${ }^{5}$ Livestock Experiment Station, Kalurkot, Bhakkar, Pakistan

\begin{abstract}
The current study was carried out to estimate the concentration of chromium $(\mathrm{Cr})$ in soil, forage, blood plasma and milk samples of Sahiwal cows collected from Kalurkoat livestock station, situated at South Western Punjab, Pakistan. The sampling was done four times at interval of two months. The concentration of $\mathrm{Cr}$ was found in the ranged $6.7-10 \mathrm{mg} /$ $\mathrm{kg}, 2.9-4.0 \mathrm{mg} / \mathrm{kg}, 3.5-4.3 \mathrm{mg} / \mathrm{L}$, and $0.4-0.6 \mathrm{mg} / \mathrm{L}$ in soil, forage, blood plasma and cows' milk respectively. The results were compared with standards values for soil, forage, blood plasma and milk. In soil, forage and plasma samples $\mathrm{Cr}$ was found higher than the standard concentration necessary for proper growth of plants and animals, whereas the level of $\mathrm{Cr}$ in milk was within standard limits. The statistical analyses indicate that the transfer of $\mathrm{Cr}$ to milk is independent of its concentration in soil-forage-blood continuum. The high concentration of $\mathrm{Cr}$ detected in forage and blood plasma implies the need for sound management of plants which absorb less quantity of chromium.
\end{abstract}

Keywords: Chromium; Livestock; Forage; Blood plasma; Soil

\section{Introduction}

Metals contamination has been causing great threat to the terrestrial as well as aquatic environment since long time. Polluted water contains undesirable material and deposits them on the soil when used for irrigation. Metals are transferred from such soil to plants and finally the herbivores. Transfer of metals from soil to plants depends upon metal speciation which in turn depends upon the feature of soil such as $\mathrm{pH}$, organic matter and clay contents [1-4].

Heavy metals are physically and chemically interrelated with natural components of the environment which consequences in altering their flow from soil to herbivores. These metals interrelate with precise compounds that may cause their precipitation or change their oxidation state. These metals bound with natural compounds resulting in increase or decrease in their mobility [5]. The high levels of bio-available heavy metals found in water, soil and fodder have significant impact on livestock. The monitoring of metal levels is helpful in ascertaining risk to human health as well as in the evaluation of environmental quality [6-8].

Heavy metal such as chromium $(\mathrm{Cr})$ is considered as one of the elements destructive to the environment and is potential bioaccumulative toxins of dairy production system. In nature it is present as chromites rocks that may form complexes under different environmental conditions. Major source of $\mathrm{Cr}$ contamination to the environment is tanning while others include electroplating, polishing, paints and pigment formation. Trivalent chromium is insoluble in water and is oxidized into hexavalent in presence of large amount of oxygen. Hexavalent chromium is potent for cancer, asthma, bronchitis and also destructive for DNA [9]. However, $\mathrm{Cr}$ is an essential metal and plays a very important role in glucose metabolism. It increases the activity of insulin because of its presence in glucose tolerance factor [10]. Although $\mathrm{Cr}$ is essential to maintain the metabolic systems of human body, it can lead to poisoning at higher level. The objective of this study was to investigate the $\mathrm{Cr}$ concentration speciation in soil and to check the accumulation of $\mathrm{Cr}$ in milk that may result in health problem of the consumers. Freidman non-parametric test shows that there seems some dependency of milk chromium on sources.

\section{Materials and Methods}

\section{Sampling duration and species}

The study was conducted during the months of October, December, February and April 2010-11 at livestock farm of Kalurkoat, District Bhakkar, South Western Punjab, Pakistan. This livestock farm was established in 1979 with total area about 3649 acres. It is located between $31^{\circ} 10^{\prime}$ and $32^{\circ} 22^{\prime} \mathrm{N}$. and $70^{\circ} 47^{\prime}$ and $72^{\circ} \mathrm{E}$. Total number of Sahiwal cows breed in this station is 512 that graze in the open ranch.

At the time of survey dominant forages species were Triffolium alexandrium, Cichorium intybus, Chinopodium morale, Medicago sativa, Avena sativa, Brassica compastrus and Alf alfa etc. Mostly the animals of Kalurkoat livestock grazed on the above mentioned forages.

\section{Categories of selected cows}

In present investigation 30 healthy animals belonging to three categories (10 sucklers, 10 milking and 10 dry cows) were selected. The milking and dry cows were 4-5 year old having average weight from $350-400 \mathrm{Kg}$. For identification, each animal had a specific number clearly imprinted on its body.

\section{Sampling}

Five acres land was selected for sampling and samples were

*Corresponding author: Dr. Muhammad Danish, Office \# 103, Chairman Department of Chemistry, Institute of Chemical and Biological Sciences, University of Gujrat, Gujrat-50700, Pakistan, Tel: +923004513193; Fax: +533643167; E-mail drdanish62@gmail.com

Received January 03, 2014; Accepted February 18, 2014; Published February 20, 2014

Citation: Danish M, Ahmad N, Sharif I, Shahzad MN, Rizvi SSR, et al. (2014) Inter-Relationship of Soil-Forage-Plasma, and Milk Chromium: A Case Study in an Arid Region of Pakistan. J Environ Anal Toxicol 4: 213. doi: 10.4172/2161 0525.1000213

Copyright: $\odot 2014$ Danish M, et al. This is an open-access article distributed under the terms of the Creative Commons Attribution License, which permits unrestricted use, distribution, and reproduction in any medium, provided the original author and source are credited. 
collected from each acre. In this way 20 samples were collected each time. Soil samples were taken from depth of $20 \mathrm{~cm}$. From the same site 20 samples of different forages were collected which were mostly grazed by animals. The forage samples were plucked from the height of $3-6 \mathrm{~cm}$ from ground to stimulate the grazing behavior of animals [11]. These samples were dried under shade, heated at $70^{\circ} \mathrm{C}$ for $72 \mathrm{hrs}$ in an electric oven and stored in plastic bags.

Blood samples were collected by puncturing the jugular vein with a syringe and needle and transferred into evacuated tubes containing heparin as an anticoagulant. The plasma was separated by centrifugation and transferred into polyethylene tubes and frozen at $-20 \mathrm{oC}$ for $\mathrm{Cr}$ detection. For milk sampling, the animals' teat were thoroughly washed and then dried. Milk was collected in $125 \mathrm{ml}$ nalgene bottles using the first drawn milk [12].

\section{Sample preparation}

For each set of processed sample, blanks (deionized water and reagents) were included throughout the entire sample preparation and analytical process.

Soil samples were dried at $70^{\circ} \mathrm{C}$ and grounded in an agate mortar. One gram of dry and powdered soil was transferred to digestion flask and $10 \mathrm{ml}$ of conc. $\mathrm{HNO}_{3}$ was then added. This mixture of soil and acid heated for 30 minutes. Further $10 \mathrm{ml}$ of conc. $\mathrm{HNO}_{3}$ was added and heated until mixture became clear. Then $10 \mathrm{ml}$ of conc. $\mathrm{HCl}$ was added and again heated till solution was reduced to half of its volume. At the end solution was filtered and diluted with distilled water up to $20 \mathrm{ml}[13]$.

One gram of each forage samples was digested with the help of $\mathrm{HNO}_{3}$ and $\mathrm{HClO}_{4}(3: 1)$ at $250^{\circ} \mathrm{C}$ for $3-4$ hours until solution become colorless and thick white fumes appeared in the flask. The contents of flask were diluted with distilled water, filtered and sample was made up to $20 \mathrm{ml}$ [14].

The hyperanized blood was centrifuged and then $2 \mathrm{ml}$ of blood plasma was taken and mixed with $2 \mathrm{ml}$ of $\mathrm{HNO}_{3}$. The mixture was digested by heating at $120^{\circ} \mathrm{C}$ until all the organic matter was dissolved. The digestion process was enhanced by adding $2 \mathrm{ml}$ of $\mathrm{H}_{2} \mathrm{O}_{2}$ to the reaction mixture and heated again. The digested sample was cooled, filtered and diluted up to $20 \mathrm{ml}$ with distilled water [15].

Milk, $10 \mathrm{ml}$ of was taken in dry pyrex digestion flask, $10 \mathrm{ml}$ of $65 \%$ $\mathrm{HNO}_{3}$ and $3 \mathrm{ml}$ of $30 \% \mathrm{H}_{2} \mathrm{O}_{2}$ was added and heated until the solution become transparent. The mixture was filtered with Whattman filter paper 40 and made up volume to $20 \mathrm{ml}$ using distilled water [16].

\section{Sample analysis}

The concentrations of chromium in soil, forage, plasma and milk were quantified by flame atomic absorption spectrophotometry using a Shimadzu atomic absorption spectrophotometer (AA-6300) coupled with a graphite furnace atomizer (GFA-EX7i). The standard burner and air-acetylene was applied as fuel. The wavelength of $\mathrm{Cr}$ was $267.2 \mathrm{~nm}$. The values were expressed in $\mathrm{mg} / \mathrm{L}$ of blood or milk and $\mathrm{mg} / \mathrm{kg}$ of soil or forage.

\section{Statistical analysis}

Statistical analysis was performed for the descriptive statistics to define the basic characteristics of the chromium concentration. To determine the significance difference among the mean concentration with respect to the time and source non-parametric Friedman test was applied. Pearson's correlation was established to describe the association between the different categories.

\section{Results and Discussion}

\section{Chromium concentration in soil, forage, blood plasma and milk}

It is evident from statistical analysis that effect of sampling time on soil $\mathrm{Cr}$ was significant. The concentration of $\mathrm{Cr}$ in soil samples ranged from $6.7-10 \mathrm{mg} / \mathrm{kg}$ (Figure 1a). The higher amount of Cr in soil samples was found during the 1st sampling (October) and lower amount of soil $\mathrm{Cr}$ was found during the 4th sampling (April). The concentration of $\mathrm{Cr}$ in soil samples was found lower than the value reported by many authors [17-19].

The concentration of forage Cr varied from $2.9-4.0 \mathrm{mg} / \mathrm{kg}$ (Figure 1b). The higher amount of forage $\mathrm{Cr}$ was found during February and the lower amount during December. The concentration of $\mathrm{Cr}$ in forage samples was found higher than the values reported in literature [20,21].

The concentration of blood Cr fluctuated from 3.5-4.3 mg/L (Figure 1c). The higher and lower amounts of blood $\mathrm{Cr}$ were found during February and December respectively. The quantity of blood Cr was found higher than the value suggested by authors [21,22].

Range of milk Cr diverged from 0.4-0.6 mg/L (Figure 1d). The higher amount of milk $\mathrm{Cr}$ was found during the 1st sampling in October and during the 3rd sampling in February. The concentration of $\mathrm{Cr}$ in milk samples was found lower than that reported in literature [21,23-26].

Freidman test, a substitute of analysis of variance (ANOVA) was applied to observe the possible difference in the mean concentration of $\mathrm{Cr}$ due to different sources (Soil, forage, milk and blood) and in different months (October, December, February and April). One of the basic assumptions of the ANOVA is the homogeneity of the variances, but that is strongly rejected by the Levene's test. Due to this reason the analysis was performed by the non-parametric Freidman test [27]. The results of this test showed that the p-values less than the level of significance (even than 0.005). Therefore the average effect on concentration level of $\mathrm{Cr}$ in different months and due to different sources is significantly not same.

Since the equality of averages is rejected, so Bonferroni multiple comparison test is applied to determine which average $\mathrm{Cr}$ concentration is different and which averages are same in different months (Table 1). The same treatment is used for different sources (Table 2).

Concentration level of $\mathrm{Cr}$ is same where lower bound and upper bound contain zero or p-value greater than 0.05 as in October and in February. Concentration level is different where lower bound and upper bound does not contain zero or p-value greater than 0.05 as in October and in December.

\section{Correlation among soil, forage, blood plasma and milk}

Pearson method was used to find the correlation between soil, forage, blood plasma and milk $\mathrm{Cr}$ concentrations. The correlation coefficient $(\mathrm{r})$ value between soil and forage $\mathrm{Cr}$ was found to be -0.15 , soil and blood 0.14 , soil and milk 0.19 , forage and blood -0.31 , forage and milk -0.08 , blood and milk -0.33 . There was found a negative and significant relationship between soil and forage, and forage and plasma Cr levels whereas a positive and significant was established between soil and plasma, soil and milk, and blood and milk Cr levels. A negative 

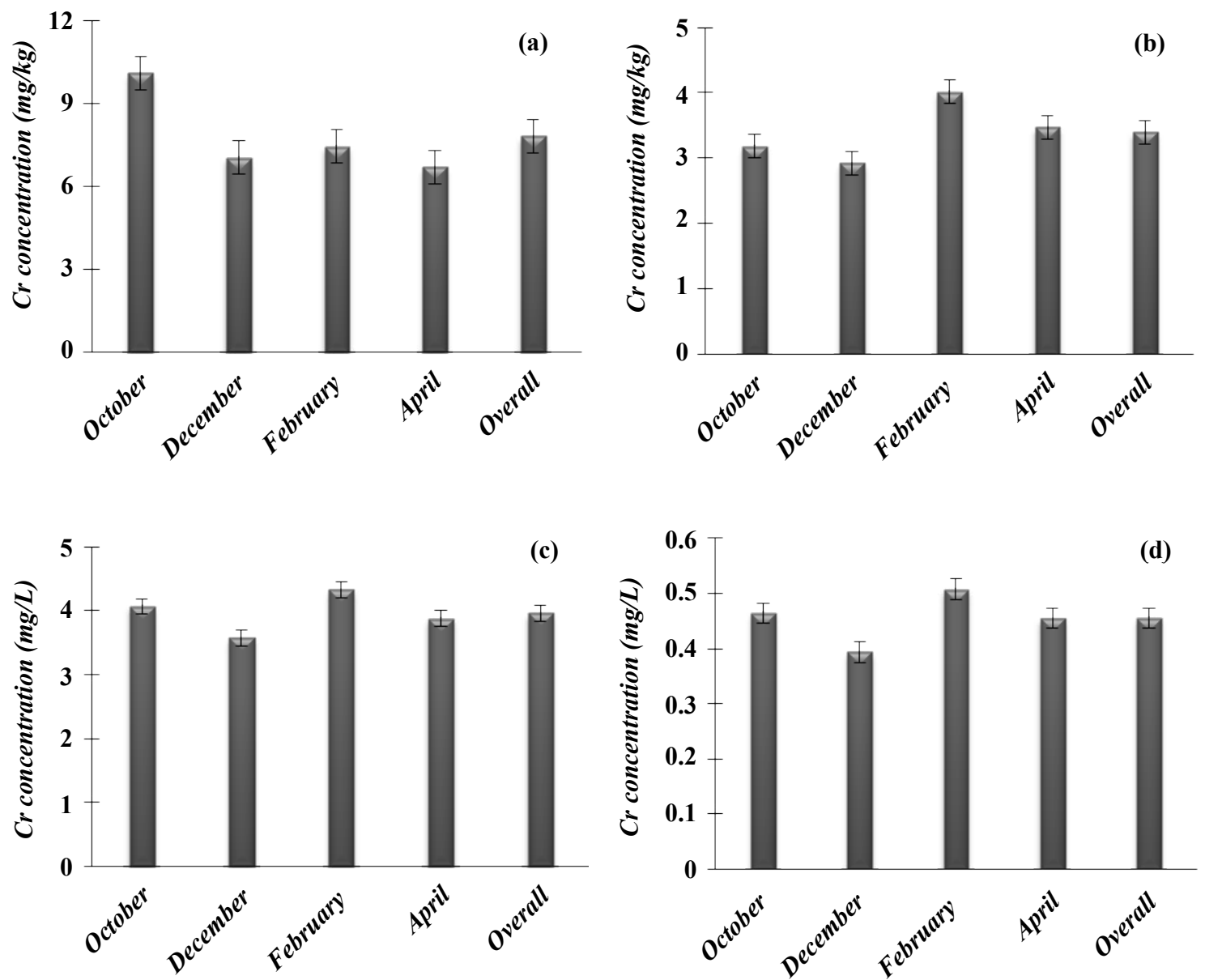

Figure 1: Average fluctuation level of chromium concentration in various samples of; (a) soil, (b) forage, (c) blood, (d) milk, according to time

\begin{tabular}{|c|c|c|c|c|c|c|}
\hline \multirow{2}{*}{ Month (I) } & \multirow{2}{*}{ Month (J) } & \multirow{2}{*}{ Mean Difference (I-J) } & \multirow{2}{*}{ Std. Error } & \multirow{2}{*}{ Sig. } & \multicolumn{2}{|c|}{$95 \%$ Confidence Interval } \\
\hline & & & & & Lower Bound & Upper Bound \\
\hline \multirow{3}{*}{ October } & December & $1.0190^{*}$ & 0.24471 & 0.000 & 0.3692 & 1.6689 \\
\hline & February & 0.3496 & 0.24471 & 0.925 & -0.3002 & 0.9995 \\
\hline & April & $0.8507^{*}$ & 0.24471 & 0.003 & 0.20085 & 1.5006 \\
\hline \multirow{3}{*}{ December } & October & $-1.0190^{*}$ & 0.24471 & 0.000 & -1.6588 & -0.3692 \\
\hline & February & $-0.6694^{*}$ & 0.24471 & 0.040 & -1.3192 & -0.0195 \\
\hline & April & -0.1683 & 0.24471 & 1.000 & -0.8182 & 0.4816 \\
\hline \multirow{3}{*}{ February } & October & -0.3496 & 0.24471 & 0.925 & -0.9995 & 0.3002 \\
\hline & December & $0.6694^{*}$ & 0.24471 & 0.040 & 0.0195 & 1.3192 \\
\hline & April & 0.5011 & 0.24471 & 0.249 & -0.1488 & 1.1509 \\
\hline \multirow{3}{*}{ April } & October & $-0.8507^{*}$ & 0.24471 & 0.003 & -1.5006 & -0.2008 \\
\hline & December & 0.1683 & 0.24471 & 1.000 & -0.4815 & 0.8182 \\
\hline & February & -0.5011 & 0.24471 & 0.249 & -1.1509 & 0.1488 \\
\hline
\end{tabular}

*The mean difference is significant at the 0.05 level

Table 1: Bonferroni multiple comparison test of means chromium concentration due to month.

and non-significant relationship was found between forage and milk $\mathrm{Cr}$ concentrations in this investigation.

\section{Chromium concentration in various blood samples during different sampling times}

Sampling period also affected the blood plasma $\mathrm{Cr}$ concentration significantly (Figure 2). It is evident from the Friedman test that there is significant effect of sampling time and blood source on milk chromium. As the p-values of month are less than the level of significance $(0.0001)$ it is concluded that the different months (October, December, February and April) affect the accumulation of this mineral in plants, blood and eventually in milk based on the results of Bonferroni multiple comparison test (Table 3). 


\begin{tabular}{|c|c|c|c|c|c|c|}
\hline \multirow{2}{*}{ Source (I) } & \multirow{2}{*}{ Source (J) } & \multirow{2}{*}{ Mean Difference (I-J) } & \multirow{2}{*}{ Std. Error } & \multirow{2}{*}{ Sig. } & \multicolumn{2}{|c|}{ 95\% Confidence Interval } \\
\hline & & & & & Lower Bound & Upper Bound \\
\hline \multirow{3}{*}{ Soil } & Forage & $4.4230^{*}$ & 0.24471 & 0.000 & 3.7731 & 5.0728 \\
\hline & Blood & $3.8569^{*}$ & 0.22339 & 0.000 & 3.2637 & 4.4502 \\
\hline & Milk & $7.3653^{*}$ & 0.29971 & 0.000 & 6.5694 & 8.1612 \\
\hline \multirow{3}{*}{ Forage } & Soil & $-4.4230^{*}$ & 0.24471 & 0.000 & -5.0728 & -3.7731 \\
\hline & Blood & -0.5661 & 0.22339 & 0.071 & -1.1593 & 0.0272 \\
\hline & Milk & $2.9423^{*}$ & 0.29971 & 0.000 & 2.1464 & 3.7383 \\
\hline \multirow{3}{*}{ Blood } & Soil & $-3.8569^{*}$ & 0.22339 & 0.000 & -4.4502 & -3.2637 \\
\hline & Forage & 0.5661 & 0.22339 & 0.071 & -0.0272 & 1.1593 \\
\hline & Milk & $3.5084^{*}$ & 0.28257 & 0.000 & 2.7580 & 4.2588 \\
\hline \multirow{3}{*}{ Milk } & Soil & $-7.3653^{*}$ & 0.29971 & 0.000 & -8.1612 & -6.5694 \\
\hline & Forage & $-2.9423^{*}$ & 0.29971 & 0.000 & -3.7383 & -2.1464 \\
\hline & Blood & $-3.5084^{*}$ & 0.28257 & 0.000 & -4.2598 & -2.7580 \\
\hline
\end{tabular}

*The mean difference is significant at the 0.05 level

Table 2: Bonferroni multiple comparison test of means chromium concentration due to source.
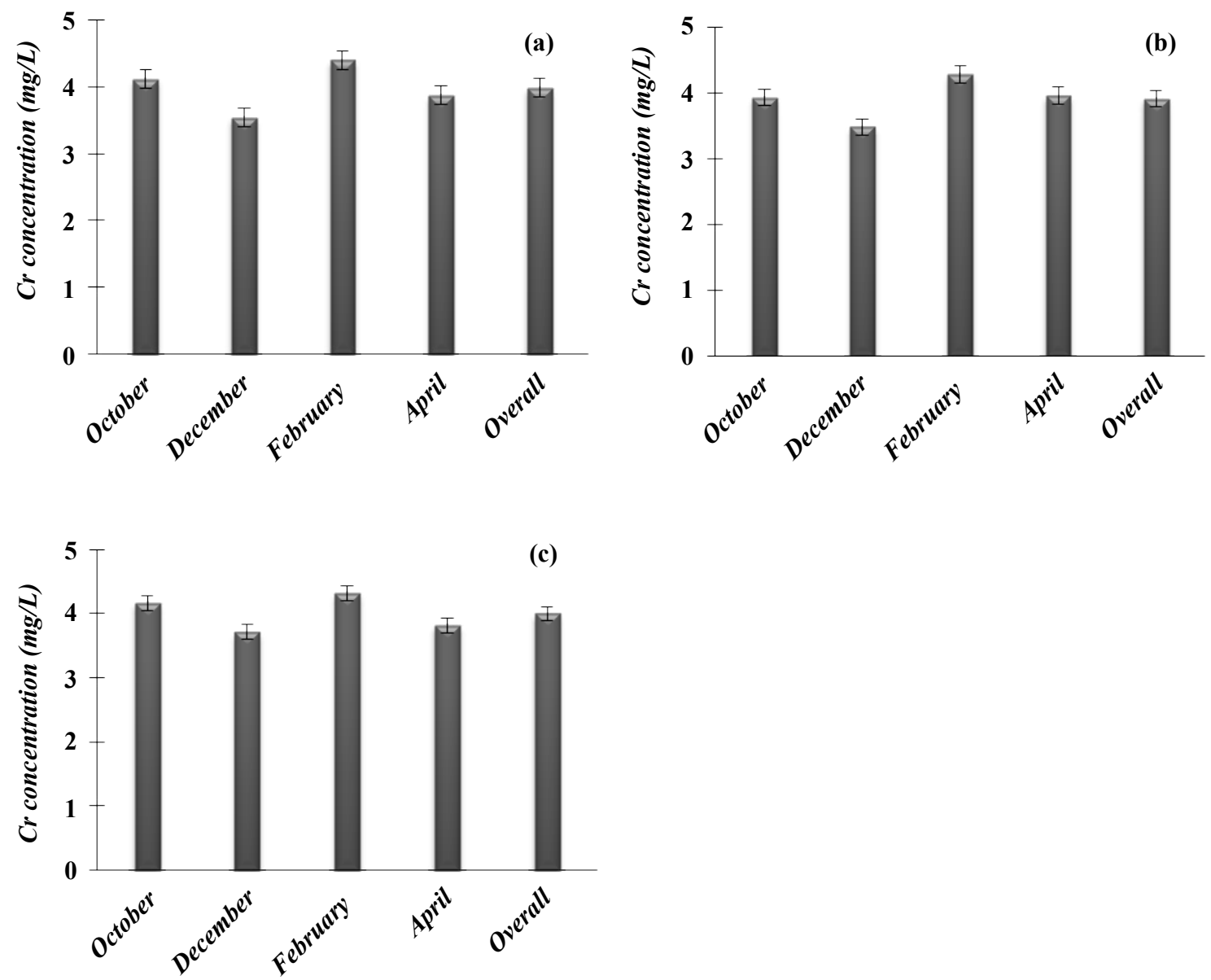

Figure 2: Average fluctuation level of chromium concentration in various blood samples of; (a) young, (b) lacto, (c) dry cows, according to time.

It was also assumed that different sources of blood (Young, Lacto and Dry) may affect the concentration level of $\mathrm{Cr}$ or there might be any interaction between months and sources of blood which play the role in the concentration level. So we can conclude that the average effect of different month on concentration level is different, when we consider only blood with three level of source (Young, Lacto and Dry).

These results show that there is continuous fluctuation in concentration of $\mathrm{Cr}$ uptake by plants. It decreases from October to December and again increases, becomes maximum in February. There is again decrease in its concentration in April. The same trend is found in the blood plasma and milk of the selected cows. However these ranges do not enter the dangerous limits. We were expecting that there could be more $\mathrm{Cr}$ accumulation in the blood of sucklers as they intake through milk as well as grazing. However, this is not the case and the 


\begin{tabular}{|c|c|c|c|c|c|c|}
\hline \multirow[t]{2}{*}{ Month (I) } & \multirow{2}{*}{ Month (J) } & \multirow{2}{*}{ Mean Difference (I-J) } & \multirow{2}{*}{ Std. Error } & \multirow{2}{*}{ Sig. } & \multicolumn{2}{|c|}{ 95\% Confidence Interval } \\
\hline & & & & & Lower Bound & Upper Bound \\
\hline \multirow{3}{*}{ October } & December & $0.4899^{*}$ & 0.15384 & 0.011 & 0.0764 & 0.9033 \\
\hline & February & -0.2646 & 0.15384 & 0.530 & -0.6781 & 0.1489 \\
\hline & April & 0.1879 & 0.15384 & 1.000 & -0.2255 & 0.6014 \\
\hline \multirow{3}{*}{ December } & October & $-0.4899^{*}$ & 0.15384 & 0.011 & -0.9033 & -0.0764 \\
\hline & February & $-0.7545^{\star}$ & 0.15384 & 0.000 & -1.1679 & -0.3410 \\
\hline & April & -0.3019 & 0.15384 & 0.314 & -0.7154 & 0.1115 \\
\hline \multirow{3}{*}{ February } & October & 0.2646 & 0.15384 & 0.530 & -0.1489 & 0.6781 \\
\hline & December & $0.7545^{*}$ & 0.15384 & 0.000 & 0.3410 & 1.1679 \\
\hline & April & $0.4525^{*}$ & 0.15384 & 0.024 & 0.0391 & 0.8660 \\
\hline \multirow{3}{*}{ April } & October & -0.1879 & 0.15384 & 1.000 & -0.6014 & 0.2255 \\
\hline & December & 0.3019 & 0.15384 & 0.314 & -0.1115 & 0.7154 \\
\hline & February & $-0.4525^{*}$ & 0.15384 & 0.024 & -0.8660 & -0.0391 \\
\hline
\end{tabular}

*The mean difference is significant at the 0.05 level

Table 3: Bonferroni multiple comparison test of means chromium concentration due to month.

Cr concentrations in their blood followed the same trends as that of other cows.

The $\mathrm{Cr}$ concentration range for livestock requirement is 0.3 to $1.6 \mathrm{mg} / \mathrm{kg}$ [21]. There is no threshold limit of maximum chromium concentration but different reports suggested a concentration between 0.03 to $1.0 \mathrm{mg} / \mathrm{kg}[28,29]$. A range of $0.156-0.285 \mathrm{mg} / \mathrm{g}$ of chromium was reported in the salt-range Pakistan [30] whereas its concentration was reported 0.0003 to $0.0006 \mathrm{mg} / \mathrm{L}$ in central Punjab Pakistan [21]. The higher level are toxic to livestock and badly affects the reproductive potential of ruminants [31,32]. The tolerance limit of $\mathrm{Cr}$ in milk is reported $0.3 \mathrm{mg} / \mathrm{kg}$ (GB/T 1461-94). The concentration of $\mathrm{Cr}$ in milk samples was found $(0.4-0.6 \mathrm{mg} / \mathrm{L})$ near the range of the certified value $(0.39 \mathrm{mg} / \mathrm{kg})$ [33] while in soil, forage and blood plasma samples was found higher than the normal values. It means that transfer of $\mathrm{Cr}$ to milk is independent of its concentration in soil, forage and blood.

\section{Conclusion}

In the present case the concentration of $\mathrm{Cr}$ ranged from 6.7$10 \mathrm{mg} / \mathrm{kg}, 2.9-4.0 \mathrm{mg} / \mathrm{kg}, 3.5-4.3 \mathrm{mg} / \mathrm{L}$, and $0.4-0.6 \mathrm{mg} / \mathrm{L}$ in soil, forage, blood plasma and cows' milk respectively. The concentration of $\mathrm{Cr}$ in milk samples was found $(0.4-0.6 \mathrm{mg} / \mathrm{L})$ near the range of the certified value $(0.39 \mathrm{mg} / \mathrm{kg})$ while in soil, forage and blood plasma samples was found higher than the normal values. It means that transfer of Cr to milk is independent of its concentration in soil, forage and blood. Although there is no adverse effect of higher concentration of $\mathrm{Cr}$ in forage and blood plasma, yet it can be decreased using the plants which absorb less quantity of chromium. Furthermore, a dietary supplementation of area specific metals and minerals mixture is suggested in order to safeguard the environment and preserve human health.

\section{Acknowledgement}

Livestock and Dairy Development Department of Punjab, Pakistan, is thanked for facilitation at Kallurkoat Livestock station.

\section{References}

1. Yebpella GG, Magomya AM, Udiba UU, Gandu I, Amana SM, et al. (2011) Assessment of $\mathrm{Cd}, \mathrm{Cu}, \mathrm{Mn}$ and $\mathrm{Zn}$ levels in soil, water and vegetABLE grown in irrigated farm along river Kubani, Zaria, Nigeria. J Appl Environ Biol Sci 1: 84-89.

2. Rajaganapathy V, Xavier F, Sreekumar D, Mandal, PK (2011) Heavy metal contamination in soil, water and fodder and their presence in livestock and products: a review. Journal of Environmental Science and Technology 4: 234249.

3. Notten MJ, OosthoekAJ, Rozema J, Aerts R (2005) Heavy metal concentrations in a soil-plant-snail food chain along a terrestrial soil pollution gradient. Environ Pollut 138: 178-190.

4. Rosas I, Belmont R, Armienta A, Baez A (1999) Arsenic concentrations in water, soil, milk and forage in Comarca Lagunera, Mexico. Water, Air, \& Soil Pollution 112: 133-149.

5. Dube A, Kowalkowski RZT, Cukrowska E, Buszewski B (2001) Adsorption and migration of heavy metals in soil. Polish Journal of Environmental Studies 10: 1-10.

6. Devasena B, Ramana JV, Prasad PE, Sudheer S, Prasad JR (2012) Chromium concentration in soil, feeds and plasma of animals in Chittoor district of Andhra Pradesh. Indian Journal of Animal Nutrition 29: 384-387.

7. Ogabiela EE, Udiba UU, Adesina OB, Hammuel C, Ade-Ajayi FA, et al. (2011) Assessment of metal levels in fresh milk from cows grazed around Challawa Industrial Estate of Kano, Nigeria. J Basic Appl Sci Res 1: 533-538.

8. Ogundiran MB, Ogundele DT, Afolayan PG, Osibanjo O (2012) Heavy metals levels in forage grasses, leachate and lactating cows reared around lead slag dumpsites in Nigeria. International Journal of Environmental Research 6: 695-702.

9. Peralta-Videa JR, Lopez ML, Narayan M, Saupe G, Gardea-Torresdey J (2009) The biochemistry of environmental heavy metal uptake by plants: implications for the food chain. Int J Biochem Cell Biol 41: 1665-1677.

10. Miranda M, Benedito JL, Blanco-Penedo I, Lopez-Lamas C, Merino A, et al. (2009) Metal accumulation in cattle raised in a serpentine-soil area: Relationship between metal concentrations in soil, forage and animal tissues. Journal of Trace Elements in Medicine and Biology 23: 231-238.

11. Sanchez PA (1981) Suelos del Tropico: Charecteristicas y manejo. IICA, San Jose, Costa Rica, 226-254.

12. Khan ZI, Ashraf M, Danish M, Ahmad K (2007) Temporal variability in the transfer of sodium from soil and dietary sources to grazing livestock in a semiarid ranch, Punjab, Pakistan. Pak J Bot 39: 1113-1121.

13. Vidovic M, Sadibasic A, Cupic S, Lausevic M (2005) Cd and Zn in atmospheric deposit, soil, wheat, and milk. Environ Res 97: 26-31.

14. AOAC (1990) Official Methods of the Association of Analytical Chemists, 14th edn. Arlington, Virginia, USA.

15. López Alonso M, Benedito JL, Miranda M, Castillo C, Hernández J, et al. (2000) Arsenic, cadmium, lead, copper and zinc in cattle from Galicia, NW Spain. Sci Total Environ 246: 237-248.

16. Jigam AA, Dauda BEN, Jimoh T, Yusuf NH, Umar ZT (2011) Determination of copper, zinc, lead and some biochemical parameters in fresh cow milk from different locations in Niger State, Nigeria. African Journal of Food Science 5 156-160.

17. Adelekan BA, Alawode AO (2011) Contributions of municipal refuse dumps to heavy metals concentrations in soil profile and groundwater in Ibadan Nigeria. Journal of Applied Biosciences 40: 2727-2737.

18. Ahmadpour P, Nawi AM, Abdu A, Abdul-Hamid H, Singh DK, et al. (2010) Uptake of heavy metals by Jatropha curcas L. planted in soils containing sewage sludge. American Journal of Applied Sciences 7: 1291-1299. 
Citation: Danish M, Ahmad N, Sharif I, Shahzad MN, Rizvi SSR, et al. (2014) Inter-Relationship of Soil-Forage-Plasma, and Milk Chromium: A Case Study in an Arid Region of Pakistan. J Environ Anal Toxicol 4: 213. doi: 10.4172/2161-0525.1000213

Page 6 of 6

19. Malik RN, Husain SZ, Nazir I (2010) Heavy metal contamination and accumulation in soil and wild plant species from industrial area of Islamabad, Pakistan. Pak J Bot 42: 291-301.

20. Tijani MN, Agakwu AA (2007) An Assessment of soil-plant transfer of trace metals and contamination of shallow groundwater under amended irrigated fields. African Crop Science Conference Proceedings 8: 1693-1697.

21. Khan Zl, Ahmad K, Raza N, Al-Qurainy F, Ashraf M, et al. (2010) Assessment of chromium concentrations in soil-plant-animal continuum: Possible risk for grazing cattle. Pak J Bot 42: 3409-3414.

22. Raj BG, Patnaik MC, Babu SP, Kalakumar B, Singh MV, et al. (2006) Heavy Metal contaminants in water-soil-plant-animal continuum due to pollution of Musi river around Hyderabad in INDIA. Indian Journal of Animal Sciences 76: 131-133.

23. Aslam B, Javed I, Khan FH, Rehman ZU (2011) Uptake of heavy metal residues from sewerage sludge in the milk of goat and cattle during summer season. Pakistan Veterinary Journal 31: 75-77.

24. Ataro A, McCrindle RI, Botha BM, McCrindle CME, Ndibewu PP (2008) Quantification of trace elements in raw cow's milk by inductively coupled plasma mass spectrometry (ICP-MS). Food Chemistry 111: 243-248.

25. Khattak RA, Haq MU, Puno HK, Saif MS (2004) Forage induced dairy milk contamination. Journal of the Chemical Society of Pakistan 26: 279-285.

26. Larranaga SC, Blasco NI (2009) Chemometric analysis of minerals and trace elements in raw cow milk from the community of Navarra, Spain. Food Chemistry 112: 189-196.

27. Derrac J, García S, Molina D, Herrera F (2011) A practical tutorial on the use of nonparametric statistical tests as a methodology for comparing evolutionary and swarm intelligence algorithms. Swarm and Evolutionary Computation 1: 3-18.

28. Güler Z (2006) Levels of 24 minerals in local goat milk, its strained yoghurt and salted yoghurt (tuzlu yoğurt). Small Ruminant Research 71: 130-137.

29. Póti P, Pajor F, Bodnár Á, Bárdos L (2012) Accumulation of some heavy metals $(\mathrm{Pd}, \mathrm{Cd}$ and $\mathrm{Cr}$ ) in milk of grazing sheep in north-east Hungary. Journal of Microbiology, Biotechnology and Food Sciences 2: 389-394.

30. Ahmad K, Khan ZI, Ashraf M, Valeem EE, Shah ZA, et al. (2009) Determination of forage concentrations of lead, nickel and chromium in relation to the requirements of grazing ruminants in the Salt Range, Pakistan. Pakistan Journal of Botany 41: 61-65.

31. Anonymous (1997) The Role of Chromium in Animal Nutrition, National Academy Press, Washington, DC.

32. McDowell LR, Arthington JD (2005) Minerals for Grazing Ruminants in Tropical Regions. Extetnsion Bulletin, Animal Science Department, University of Florida, USA.

33. Qin LQ, Wang XP, Li W, Tong X, Tong WJ (2009) The minerals and heavy metals in Cow's milk from China and Japan. Journal of Health Science 55 300-305. 